\title{
Implementasi Kebijakan Pembebasan Biaya Kesehatan Dasar
}

\begin{abstract}
Akadun
ABSTRACT

This study aims to analisys the role organization communication in implementing public policy of free-cost of basic health service. The result indicate that organization communication role for depending in implementing public policy successfull and become trigger other critical factor of implementing policy succesfull, as like resource, bureaucratic structure, and disposition or attitude. Quality of information media, information accessibility, information fidelity, information spreading, information load is urgent to implementing public policy successful.
\end{abstract}

Kata kunci: komunikasi organisasi, implementasi kebijakan, kesehatan dasar

\section{Pendahuluan}

Kesehatan merupakan variabel penting bagi kinerja manusia. Manusia yang sehat jasmani dan rohani dapat meningkatkan produktivitas kerjanya dan dapat memberikan nilai tambah bagi dirinya maupun bagi bangsa dan negaranya. Oleh karena itu, pembangunan kesehatan merupakan bagian integral pembangunan manusia seutuhnya.

Kesehatan merupakan hak asasi setiap manusia seperti tertuang dalam Undang-undang Nomor 23 Tahun 1992 tentang Kesehatan yang menyebutkan bahwa kesehatan merupakan hak asasi setiap orang dan setiap orang memiliki hak yang sama untuk memeroleh derajat kesehatan yang optimal. Ketentuan ini mewajibkan negara (pemerintah) untuk memberikan pemerataan pelayanan kesehatan kepada masyarakat.

Menyadari bahwa sebagian anggota masyarakat berada di bawah garis kemiskinan sehingga kesulitan biaya dalam mengakses pelayanan kesehatan, maka Pemerintah Kabupaten Sumedang mengeluarkan kebijakan program pembebasan biaya pelayanan kesehatan dasar masyarakat. Kebijakan pembebasan biaya pelayanan kesehatan dasar tersebut dituangkan dalam pasal 7 Peraturan Daerah Kabupaten Nomor 8 Tahun 2006 tentang Pelayanan Kesehatan di Unit Pelaksana Teknis Dinas Pusat Kesehatan Masyarakat. Dalam ketentuan ini, Puskesmas diwajibkan untuk mengatur penyelenggaraan pelayanan kesehatan bagi penduduk yang menggunakan jasa pelayanan kesehatan, perlu menetapkan standar operasional prosedur pelayanan kesehatan di UPTD Puskesmas.

Pengaturan penyelenggaraan pelayanan kesehatan pada Puskesmas sangat penting, karena Puskesmas merupakan unit pelayanan kesehatan yang paling dekat dengan masyarakat. Namun, dalam implementasi kebijakan pembebasan biaya pelayanan kesehatan dasar bebas di lapangan berjalan kurang optimal, dengan indikator sebagai 
berikut:

(1) Pelaksana kebijakan kurang mengomunikasikan kebijakan pembebasan biaya pelayanan kesehatan dasar ini kepada masyarakat, sehingga menimbulkan ketidakpuasan masyarakat,

(2) kurangnya komunikasi organisasi antara pengambil kebijakan dengan pelaksana kebijakan, sehingga muncul perilaku pelaksana yang kurang mendukung pelaksanaan kebijakan seperti pelayanan kepada pasien yang kurang memuaskan, keterlambatan dalam penyelesaian pekerjaan, dan masih terdapat pegawai yang mengalami keterlambatan dalam masuk kerja.

(3) Kurangnya sumber daya pendukung pelaksanaan pelayanan dan ruang kerja kurang nyaman sehingga mengurangi optimalisasi kinerja pegawai.

Bertitik tolak dari latar belakang di atas maka penulis merumuskan pertanyaan penelitian sebagai berikut, "Bagaimana peranan komunikasi organisasi dalam implementasi kebijakan program pembebasan biaya pelayanan kesehatan dasar di Puskesmas Tomo Kabupaten Sumedang?" Berdasarkan pertanyaan penelitian di atas maka tujuan penelitian ini adalah, "menganalisis peranan komunikasi organisasi dalam implementasi kebijakan program pembebasan biaya pelayanan dasar di Puskesmas Tomo Kabupaten Sumedang”.

\section{Tinjauan Teoretis}

Komunikasi organisasi dalam implementasi kebijakan program pembebasan biaya pelayanan kesehatan dasar dapat dikaji dari berbagai bidang ilmu, termasuk di dalamnya bidang ilmu Administrasi Publik. Pfiffner and Presthus (1967:7) menyatakan, "Public administration may be defined as the coordination of individual and group efforts to carry out public policy". Artinya, administrasi publik dapat dirumuskan sebagai koordinasi usaha-usaha individu dan kelompok untuk melaksanakan kebijakan publik. Dengan demikian, komunikasi organisasi dalam implementasi kebijakan program pembebasan biaya pelayanan kesehatan dasar juga merupakan kajian Administrasi Publik.

Pernyataan Pfiffner dan Presthus di atas didukung oleh Turner and Hulme (1997:5) berikut ini:

Both the public and development professionals identify the formulation, and, and to various degree the implementation, of policy as the prime task of government. It is believed that government should be generating economic growth, providing education, quaranteing personal safety, expanding job opportunities, and taking many other initiatives which should lead to development.

Dari pendapat Turner dan Hulme di atas terungkap bahwa tugas utama pemerintah adalah memformulasi dan mengimplementasikan kebijakan. Dari tugas ini dapat terdeskripsikan fungsi-fungsi pemerintah sebagai pembuat kebijakan dan pengaturan, sebagai pemberi pelayanan, dan sebagai pemberdaya komponen negara lainnya (masyarakat dan pihak swasta). Fungsi-fungsi tersebut dapat dilakukan pemerintah apabila pemerintah mampu membuat kebijakan dan mengimplementasi-kannya dengan baik.

Pemerintah dapat mengimplementasikan kebijakan yang telah dibuat dengan baik manakala pemerintah memperhatikan faktor-faktor kritis atau variabel: komunikasi, sumberdaya, disposisi atau sikap implementator, dan struktur birokrasi (Edward III, 1980:9-10). Sebagai variabel penting untuk keberhasilan tugas dan fungsi pemerintah mengimplementasikan kebijakan, komunikasi sangat penting dipahami, dikaji dan diteliti oleh pegawai pemerintah.

Katz dan Kahn (dalam Pace dan Faules, 2002:66) mengatakan bahwa komunikasi merupakan inti dari sistem sosial atau organisasi itu sendiri. Wood (2001:507) mengilustrasikan communication in organizations is analogous to blood circulation in our bodies. Dengan demikian, menurut Pace dan Faules (2002: 85), mempelajari organisasi adalah mempelajari perilaku keorganisasian dan inti perilaku tersebut adalah komunikasi. Karena itu, menurut Pace dan Faules (2002:24) memperbaiki komunikasi berarti memperbaiki organisasi. Secara sederhana Wood 
Terakreditasi Dirjen Dikti SK No. 56/DIKTI/Kep/2005

(2001:507) mendefinisikan komunikasi organisasi sebagai, "Organizational communication is the process by which entities exchange information and establish a common understanding".

Dalam organisasi birokrasi (termasuk Pemerintah Daerah, Puskesmas) terdapat dua jenis komunikasi, yaitu komunikasi formal dan komunikasi informal. Komunikasi formal adalah komunikasi yang terjadi di dalam struktur formal pegawai dan biasanya tidak jauh berbeda dengan komunikasi yang hierarkis. Hal ini berlaku juga pada struktur birokrasi dalam implementasi kebijakan program pembebasan biaya pelayanan kesehatan dasar. Pejabat Dinas Kesehatan atau Kepala Puskesmas mempunyai tugas mengomunikasikan kebijakan program pembebasan biaya pelayanan kesehatan dasar kepada seluruh jajaran di bawahnya, sehingga terjadi pemahaman bersama atau merubah persepsi dan perilaku pegawai untuk mendukung implementasi kebijakan program pembebasan biaya pelayanan kesehatan dasar. Kepala Puskesmas juga memiliki kewajiban untuk mengomunikasi segala hal yang menyangkut implementasi kebijakan program pembebasan biaya pelayanan kesehatan dasar termasuk kesiapan mental pegawai, kesiapan sarana dan prasarana, kesiapan obat-obatan, wansprestasi yang bakal diterima pegawai secara transparan.

Dalam perkembangannya, ternyata komunikasi organisasi tidak hanya terjadi secara formal, tetapi juga informal. Komunikasi informal muncul karena: (1) keberadaan manusia yang tidak bisa dibatasi volume komunikasinya; (2) motivasi manusia di dalam organisasi yang berbeda-beda; (3) ada masalah organisasi yang lebih efektif diselesaikan melalui komunikasi informal; (4) terjadinya kebekuan komunikasi di dalam organisasi; dan (5) terjadinya krisis kepemimpinan dalam organisasi. Struktur komunikasi di dalam komunikasi informal sendiri berbentuk jaringanjaringan komunikasi antar manusia di dalam organisasi yang acapkali melintasi batas-batas unit kerja, bahkan jenjang kepangkatan.

Organisasi pada akhirnya harus melakukan komunikasi eksternal, yaitu komunikasi kepada lingkungannya. Tujuan komunikasi adalah menciptakan pemahaman bersama atau mengubah persepsi (dan perilaku). Demikian pula dengan komunikasi organisasi. Kepala Puskesmas sebagai pemimpin mempunyai tugas untuk mengomunikasi kebijakan program pembebasan biaya pelayanan kesehatan dasar ke masyarakat untuk memeroleh kesamaan makna dengan masyarakat terhadap kebijakan ini, sekaligus mengubah persepsi masyarakat agar mendukung kebijakan ini.

Dalam konteks organisasi, menurut Pace dan Faules (2002:496), ada lima faktor yang terlibat dalam suatu peristiwa komunikasi organisasi yang akan berpengaruh kepada bagaimana peristiwa itu dipersepsi atau diinterprestasi oleh anggota organisasi. Kelima faktor tersebut yaitu kualitas media informasi, aksesbilitas informasi, beban informasi, penyebaran informasi, dan ketepatan informasi.

Selain berpengaruh terhadap kinerja individu, komunikasi organisasi juga mempunyai pengaruh terhadap motivasi. Robbins (2001:435) mengemukakan salah satu fungsi komunikasi adalah memberikan motivasi kepada para anggota organisasi agar dapat melakukan pekerjaan dengan baik.

Agar implementasi menjadi efektif, yang bertanggung jawab untuk mengimplementasikan harus mengetahui apa yang mereka akan kerjakan. Aturan main untuk mengimplementasikan kebijakan harus ditransformasikan kepada pegawai yang bersangkutan, dan aturan main itu harus jelas, akurat, dan konsisten. Jika pengambil kebijakan ingin melihat implementasi secara spesifik tidak jelas, kebijakan itu mungkin akan disalahpami oleh mereka yang diarahkan. Kebingungan oleh pelaksana tentang apa yang dikerjakan menambah peluang bahwa kebijakan tidak terimplementasikan, sehingga tidak dapat mencapai tujuan yang dimaksud.

Komunikasi yang tidak teliti memberikan pelaksana dengan keleluasaan, sehingga mereka berupaya merumuskan kembali kebijakan-kebijakan umum ke dalam tindakan-tindakan khusus. Keleluasaan ini akan mengakibatkan ketidaksamaan dengan maksud pembuat 
keputusan yang asli. Dengan demikian, instruksi implementasi yang tidak disalurkan, mendistorsi saluran itu, atau mengakibatkan ketidakkonsistenan yang menghambat implementasi kebijakan. Namun, petunjuk yang terlalu rigid juga mengakibatkan kurangnya kreativitas dan adaptabilitas dalam implementasi. Oleh karena itu, jika ingin kebijakan yang diimplementasikan secara layak, instruksi implementasi itu tidak hanya harus diterima tetapi juga harus jelas.

\section{Metode Penelitian}

Penelitian ini menggunakan pendekatan kualitatif dengan metode studi kasus dan teknik analisis triangulasi. Pelaksanan penelitian terhadap implementasi kebijakan pembebasan biaya pelayanan kesehatan dasar di Puskesmas Tomo Sumedang.

Data yang dijaring secara konseptual merupakan pengembangan analisis variabel atau faktor kunci bagi keberhasilan implementasi kebijakan mulai dari komunikasi, sumber daya, perilaku birokrat, dan struktur birokrasi. Namun, penelitian ini lebih memfokuskan bagaimana peranan komunikasi dalam implementasi kebijakan dalam kaitannya dengan sumber daya, perilaku dan struktur birokrasi.

Teknik pengumpulan data difokuskan melalui telaahan dokumen, observasi, dan wawancara. Kegiatan tersebut dilengkapi dengan pedomanpedomannya dan catatan lapangan. Analisis data dilakukan secara terus-menerus sejak fokus penelitian ditentukan. Tahapan analisis data meliputi: menyusun kerangka tema sesuai dengan fokus penelitian, mengorganisasikan data, memilahmilahnya menjadi satuan yang dapat dikelola, mensintesiskannya, mencari dan menemukan pola, menemukan apa yang penting dan apa yang dipelajari, dan memutuskan apa yang dapat diceritakan kepada orang lain.

\section{Hasil Penelitian dan Pembahasan}

Peranan komunikasi organisasi ternyata sangat penting dalam implementasi kebijakan pembebasan biaya pelayanan kesehatan dasar. Hal ini dapat terlukiskan dalam bagaimana komunikasi internal dan eksternal dalam mengomunikasi kebijakan pembebasan biaya pelayanan kesehatan dasar seperti pada gambar 1 .

Gambar 1 dapat terdeskripsikan pola komunikasi organisasi eksternal yang digunakan Pemerintah Kabupaten Sumedang dan Puskesmas dalam mengimplementasi kebijakan pembebasan biaya pelayanan kesehatan dasar di Puskesmas. Penyebaran informasi tentang pembebasan biaya pelayanan kesehatan dasar di Puskesmas dilakukan dengan memanfaatkan birokrasi pemerintah daerah yang dimilikinya. Setelah terbitnya Perda tentang pembebasan biaya pelayanan pelayanan dasar, Dinas Kesehatan sebagai leading sector mengadakan rapat koordinasi dengan dengan Kepala UPTD Puskesmas.

Kepala Puskesmas dengan berkoordinasi dengan Camat memanfaatkan saluran komunikasi minggon (pertemuan rutin setiap Minggu antara camat dan jajarannya dengan kepala-kepala desa yang pada umumnya diadakan pada hari Senin) untuk menyosialisasikan kebijakan pembebasan biaya pelayanan kesehatan dasar di Puskesmas kepada kepala-kepala desa. Melalui saluran ini, Kepala Puskesmas mengharapkan kepada kepalakepala desa untuk meneruskan informasi kebijakan ini kepada para warganya dengan membuat Kartu Berobat Gratis ke Puskesmas. Informasi yang diterima Kepala-Kepala Desa diteruskan secara berjenjang kepada Kepala Dusun, Ketua RW, Ketua RT. Ketua-ketua RT mengimformasikan kebijakan pembebasan biaya pelayanan kesehatan dalam rapat-rapat RT.

Jika masyarakat tidak hadir dalam pertemuanpertemuan RT, masyarakat dapat memeroleh dari pegawai Puskesmas yang melakukan koordinasi atau pembinaan atau penyuluhan dalam kegiatankegiatan warga masyarakat seperti PKK, Posyandu, Dasa Wisma. Manakala saluran komunikasi lewat kegiatan-kegiatan warga tidak jalan, maka masyarakat dapat menerima informasi pembebasan biaya pelayanan kesehatan dasar pada saat masyarakat berobat kepada Puskesmas, Puskesmas Pembantu, Puskesmas Keliling, dan 
Gambar 1

Pola Komunikasi Organisasi dalam Implementasi Kebijakan Pembebasan Biaya Pelayanan Kesehatan Dasar Puskesmas

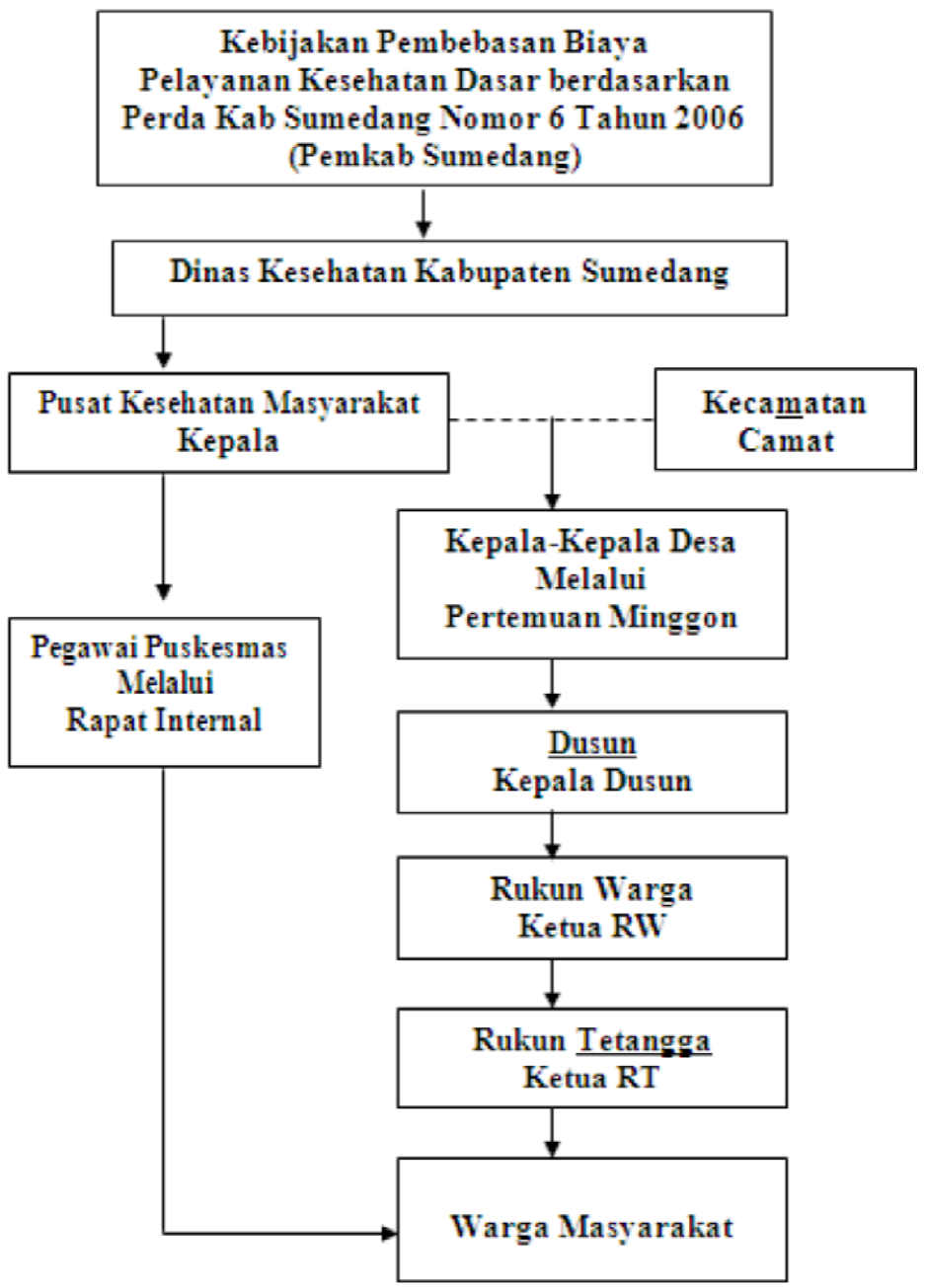

Bidan Desa.

Mengkaji saluran komunikasi yang dibangun pemerintah Kabupaten Sumedang, terutama Puskesmas dalam mengimplementasikan kebijakan pembebasan biaya pelayanan kesehatan dasar dapat disimpulkan bahwa Puskesmas telah berhasil membangun komunikasi organisasi eksternal yang efektifdengan masyarakat. Hal ini dapat dibuktikan berbagai respons positif masyarakat atas kebijakan tersebut dan masyarakat memanfaatkan kebijakan tersebut secara optimal. Efektivitas komunikasi organisasi tersebut dapat dilihat dari data kunjungan pasien ke Puskesmas Tomo Tahun 2007 yang menggunakan fasilitas bebas biaya, yaitu 
Januari (3.348 orang), Februari (3.224 orang), Maret (2.706 orang), April (2.408 orang), Mei (2.323 orang), Juni (2.085 orang), Juli (2.289 orang), Agustus (2.046 orang), September (1.751 orang), dan Oktober (1.651 orang) (Puskesmas Tomo, 2007).

Efektivitas komunikasi organisasi eksternal yang dilakukan Puskesmas Tomo telah berhasil, karena menjaga kualitas media informasi, aksesbilitas informasi yang tinggi, dan penyebaran informasi yang lancar (melalui berbagai media, mulai dari jenjang birokrasi pemerintahan daerah, saluran kegiatan masyarakat, dan jajarannya sendiri). Keberhasilan komunikasi organisasi eksternal Puskesmas dikarenakan beban informasi yang disalurkan hanya mengenai pembebasan biaya pelayanan kesehatan dasar. Namun, saluran komunikasi birokrasi berjenjang belum memberikan informasi lengkap dan jelas tentang jenis-jenis pelayanan kesehatan dasar, sehingga ketepatan informasi masih dirasa kurang. Hal ini dibuktikan dengan masih banyaknya kekecewaan masyarakat bahwa penyakitnya tidak dapat diobati oleh Puskesmas, tetapi harus dirujuk ke rumah sakit. Informasi tersebut juga baru diperoleh pasien setelah mendatangi Puskesmas untuk berobat.

Kepala Puskesmas juga telah berhasil membangun komunikasi internal dengan para pegawai di jajarannya dalam implementasi kebijakan pembebasan biaya pelayanan kesehatan dasar, terutama dengan sudah dipahaminya ruang lingkup dan pengaturan standar operasional prosedur program pembebasan biaya pelayanan kesehatan dasar. Adapun jenis dan kriteria pembebasan biaya retribusi pelayanan dasar adalah: (1) pelayanan kesehatan perorangan merupakan pelayanan kesehatan medik dasar; (2) pelayanan kesehatan masyarakat; (3) pelayanan rawat inap; (4) pelayanan kesehatan gigi sederhana; (5) tindakan gawat darurat ringan; (6) pelayanan laboratorium sederhana; (7) tindakan persalinan. Keenam jenis pelayanan tersebut di atas beserta rinciannya kadang kala tidak dimengerti oleh masyarakat, baru dimengerti masyarakat setelah mereka berobat dan mendapat penjelasan dari pegawai Puskesmas.

Para pegawai Puskesmas juga telah memahami penerima pelayanan yang bebas biaya, yaitu seluruh penduduk Sumedang, asalkan menunjukkan KTP Sumedang, maka mereka akan melayani penduduk secara gratis. Pembebasan biaya ini diberlakukan pada pengobatan di Puskesmas dan jaringannya. Kendati demikian, dalam pemberian waktu pelayanan, sering terdapat perbedaan persepsi. Misalnya, karena meskipun waktu jam kerja Puskesmas untuk Senin s.d. Kamis Pukul 07.30 s.d. 13.00 WIB, kenyataannya untuk pendaftaran pasien bisa dimulai pukul 08.30 dan ditutup pukul 10.00. Sedangkan waktu pelayanan medik bisa dimulai pukul 09.00. Hal ini mengindikasikan kurangnya disiplin dan tanggung jawab pegawai dan ketidaktaatan pegawai terhadap prosedur kerja yang telah ditetapkan mengenai pelayanan secara rinci berikut lamanya waktu penyelesaian. Banyak pekerjaan yang tidak dapat diselesaikan tepat pada waktunya.

Keterlambatan waktu pelayanan administratif dan medik bisa jadi karena ketidakberhasilan Kepala Puskesmas dalam membangun komunikasi eksternal dengan Pemkab Sumedang dan Dinas Kesehatan Sumedang. Tidak dapat dipungkiri bahwa program pembebasan biaya pelayanan kesehatan dasar mengakibatkan kunjungan pasien ke Puskesmas Tomo bertambah. Bertambahnya kunjungan pasien tidak dibarengi bertambahnya sumber daya seperti yang dipersyaratkan Edward III (1980:9-10). Kualitas dan kuantitas SDM sebagai pelaksana kebijakan tidak mencukupi. Sarana dan prasarana untuk mendukung implementasi kebijakan kurang memadai. Insentif kepada pelaksana dirasakan terlalu kecil. Demikian juga, kekurangan dan droping obat dari Dinas Kesehatan sering mengalami keterlambatan, sehingga berujung kepada ketidakpuasan pasien.

Apalagi pegawai sebagai bagian dari Puskesmas tidak hanya melaksanakan tugas yang berkaitan dengan pelayanan medis dan administratif di Puskesmas dan jaringannya saja, tetapi juga melakukan pembinaan dan penyuluhan tentang berbagai hal yang berkaitan dengan kesehatan kepada masyarakat. Para pegawai mengakui bahwa memang puskesmas mendapat insentif Rp 1.250 per pasien yang bebas biaya 
pelayanan dengan mengklaim ke Pemkab Sumedang, akan tetapi di samping keterlambatan atas pembayaran klaim juga keterbatasan dana operasional pegawai puskesmas ketika melakukan koordinasi, pembinaan, dan penyuluhan tentang kesehatan ke desa-desa. Kondisi geografis Kecamatan Tomo mengakibatkan biaya operasional untuk melakukan koordinasi, pembinaan, dan penyuluhan ke desa-desa menjadi tidak murah. Apabila kondisi ini berlanjut maka satu pihak pemerintah mengusung kebijakan yang meringankan masyarakat berobat ke Puskesmas, namun di pihak lain akan membiarkan kegiatankegiatan pembinaan dan penyuluhan masyarakat untuk mencegah timbulnya penyakit serta menjaga hidup dan lingkungan hidup sehat terbelangkai.

\section{Kesimpulan dan Saran}

Berdasarkan temuan dan pembahasan penelitian, menunjukkan komunikasi organisasi berperan dalam implementasi kebijakan program pembebasan pelayanan kesehatan dasar di Puskesmas Tomo. Kepala Puskesmas Tomo telah berhasil memanfaatkan berbagai saluran komunikasi yang telah tersedia, yaitu saluran komunikasi minggon yang merupakan ciri khas saluran komunikasi antara Camat dengan KepalaKepala Desa pada setiap minggu, juga memanfaatkan jaringan komunikasi kegiatankegiatan masyarakat seperti Posyandu, PKK, dan Dasa Wisma. Saluran komunikasi mengakibatkan media informasi yang digunakan berkualitas, sehingga dapat menyebarkan informasi tentang kebijakan pembebasan biaya pelayanan kesehatan dasar. Meskipun demikian, ketepatan informasi tentang ruang lingkup dan jenis pelayanan kesehatan dasar harus diinformasikan secara jelas lagi kepada masyarakat.

Demikian juga komunikasi formal Kepala Puskesmas dengan para pegawainya telah berhasil mengomunikasikan tentang jenis, penerima, tempat, dan jam kerja pelayanan yang dibebaskan retribusinya. Di sisi lain, masih terdapatnya perilaku pegawai yang tidak disiplin dan tidak bertanggung jawab, yang bisa jadi diakibatkan kegagalan kepala Puskesmas dalam melakukan komunikasi, baik secara formal maupun informal dengan pejabat di lingkungan Pemkab Sumedang umumnya, khususnya dengan Dinas Kesehatan Kabupaten Sumedang.

Oleh karena itu, kepada setiap pelaksana kebijakan publik selayaknya menggunakan saluran komunikasi yang tersedia dalam mengimplementasikan kebijakan sesuai dengan keunikan daerahnya. Ketepatan informasi, beban informasi, aksesbilitas informasi, teknik penyebaran informasi harus menjadi catatan penting dalam menentukan saluran komunikasi untuk mengimplementasikan kebijakan.

Setiap pelaksana kebijakan publik harus tetap menjalin komunikasi formal dan informal dengan pengambil kebijakan sehingga pengambil kebijakan tetap memperhatikan ketersediaan sumber daya dan perilaku pelaksana dalam mengimplementasikan kebijakan publik.

\section{Daftar Pustaka}

Edwards III, George C. 1980. Implementing Public Policy, Washington D.C.: Congressional Quarterly Press.

Pemerintah Republik Indonesia, Undang-Undang Nomor 23 Tahun 1992 tentang Kesehatan.

Pemerintah Daerah Kabupaten Sumedang, Peraturan Daerah Nomor 8 Tahun 2006 tentang Pelayanan Kesehatan di Unit Pelaksana Teknis Dinas Pusat Kesehatan Masyarakat.

Pfiffner, John M. and Robert Presthus. 1967. Public Administration, New York: The Ronald Press Company.

Pace, R. Wayne \& Faules, Don F. 2002. Organizational Communication. Third Edition, New Jersey: Prentice Hall, Englewood Clifs.

Robbins, P. Stephen. 2001. Organizational Behavior, 9th ed.. Upper Saddle River, New Jersey, 07458: Prentice-Hall Inc. 
Turner, Mark and David Hulme. 1997. Governance, Administration and Development, Connecticut USA: Kumarian Press, Inc.
Wood, Jack dan Joseph Wallace \& Rachid M. Zeffane. 2001. Organizational Behavior a Global Perspectives. Australia: John Willey \& Sons. 